\title{
ХАРАКТЕРИСТИКА ВІДТВОРЮВАЛЬНОЇ ЗДАТНОСТІ КОРІВ УКРАЇНСЬКИХ ЧЕРВОНО-РЯБОЇ, ЧОРНО-РЯБОЇ МОЛОЧНИХ ТА ГОЛШТИНСЬКОЇ ПОРІД У ДПДГ “ОЛЕКСАНДРІВСЬКЕ”
}

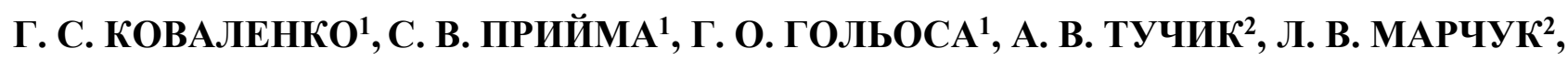 \\ В. П. ОЦАБРИК ${ }^{2}$, Б. Б. ЛЬОЛЯ ${ }^{2}$ \\ ${ }^{1}$ Інститут розведення і генетики тварин імені М.В.Зубия НААН (Чубинське, Україна) \\ 2 Державне підприємство “Дослідне господарство “Олександрівське” (Олександрівка, Україна) \\ kovalenko.5.10.g@gmail.com
}

Проведено дослідження відтворювальної здатності (вік першого осіменіння, вік першого отелення, тривалість тільності, сервіс-період, сухостійний період, міжотельний період і коефіцієнт відтворної здатності) корів украӥнських червоно-рябої, чорно-рябої молочних та голштинської порід. Встановлено, щзо телички були осіменені у віці 18,1-19,1 місяців, відповідно вік першого отелення у них становив 27,6-28,7 місячя. Середні показники сервісперіоду у изи порід становили від 135-164 днів, відповідно, міжотельний період у них був 414443 дні, щзо значно більше від оптимальних показників на 44-74 i 50-78 днів. Між надоєм $i$ показниками відтворювальної здатності одержано різновекторні коефіцієнти кореляції, низькі, як додатні, так і від'ємні ( $r=-0,001--0,278 ; r=+0,006-+0,350)$. Сила впливу $\left(\eta^{2} x\right)$ факторів на відтворювальну здатність корів вивчених порід була найвищою у батьків (10,043,6\%), потім лініі (2,3-25,5\%) і відповідно породи (0,1-1,0\%).

Ключові слова: порода, відтворювальна здатність, надій, кореляція, сила впливу

\section{CHARACTERISTICS OF REPRODUCTIVE ABILITY OF COWS UKRAINIAN RED-AND- WHITE DAIRY CATTLE AND UKRAINIAN BLACK-AND-WHITE DAIRY CATTLE AND HOLSTEIN BREEDS IN SERF “OLEKSANDRIVSKE"}

G. S. Kovalenko ${ }^{1}$, S. V. Priyma ${ }^{1}$, G. A. Holosa ${ }^{1}$, A. V. Tuchyk ${ }^{2}$, L. V. Marchuk², V. P. Otsabryk ${ }^{2}$, B. B. Lolya ${ }^{2}$

${ }^{1}$ Institute of Animal Breeding and Genetics nd. a. M.V.Zubets of NAAS (Chubynske, Ukraine)

${ }^{2}$ State Enterprise "Research Farm "Oleksandrivske” (Oleksandrivka, Ukraine)

The reproductive ability (the age of the first insemination, first calving, the duration of pregnancy, the service period, the dry period and period between calving and the coefficient of reproductive ability) cows Ukrainian Red-and-White Dairy cattle and Ukrainian Black-and-White Dairy cattle and Holstein breeds has been studied. It was established, that the heifers were inseminated at the age of 18,1-19,1 months, respectively, the age of their first calving was 27,6-28,7 months. The average indicators of service period were of these breeds from 135 to 164 days, respectively, the period between calving were 414-443 days, significantly more than the optimal performance on 44-74 and 50-78 days. The multi-vector correlation coefficients, low, positive and negative $(r=-0,001--$ $0,278 ; r=+0,006-+0,350)$, between milk yield and reproductive ability are obtained. The power of impact of factors $\left(\eta^{2} x\right)$ on the reproductive ability of the cows of the studied breeds was highest in the parents $(10,0-43,6 \%)$, then the lines $(2,3-25,5 \%)$ and, respectively, the breed $(0,1-1,0 \%)$.

Keywords: breed, reproductive ability, milk yield, correlation, power of impact 


\section{ХАРАКТЕРИСТИКА ВОСПРОИЗВОДИТЕЛЬНОЙ СПОСОБНОСТИ КОРОВ УКРА- ИНСКИХ КРАСНО-ПЕСТРОЙ, ЧЕРНО-ПЕСТРОЙ МОЛОЧНОЙ И ГОЛШТИНСКОЙ ПОРОД В ГПОХ "АЛЕКСАНДРОВСКОЕ"}

Г. С. Коваленко ${ }^{1}$, С. В. Прыйма ${ }^{1}$, Г. А. Голёса ${ }^{1}$, А. В. Тучик ${ }^{2}$, Л. В. Марчук ${ }^{2}$, В. П. Оцабрик'

${ }^{1}$ Институт разведения и генетики животных имени М.В.Зубиа НААН (Чубинское, Украина)

${ }^{2}$ Государственное предприятие “Опьтное хозяйство “Александровское” (Александровка, Украина).

Проведено исследование воспроизводительной способности (возраст первого осеменения, возраст первого отела, продолжительность стельности, сервис-период, сухостойньій период, период между отелами и коэффициент воспроизводительной способности) коров украинских красно-пестрой, черно-пестрой молочных и голитинской пород. Установлено, что телочки были оплодотворены в возрасте 18,1-19,1 месяиа, соответственно, возраст первого отела у них составлял 27,6-28,7 месяиа. Средние показатели сервис-периода у этих пород составляли от 135 до 164 дней, соответственно, период между отелами у них был 414-443 дней, что значительно больше оптимальных показателей на 44-74 и 50-78 дней. Между удоем и показателями воспроизводительной способности получено разно векторные коэффициенты корреляции, низкие, как положительные, так и отрииательные ( $r=-0,001$ - $0,278 ; r=+0,006-+0,350)$. Сила влияния $\left(\eta^{2} x\right)$ факторов на воспроизводительную способность коров изученных пород была самой высокой у отщов (10,0-43,6\%), затем линии (2,325,5\%) и соответственно породы (0,1-1,0\%).

Ключевые слова: порода, воспроизводительная способность, надой, корреляция, сила влияния

Вступ. Створення високопродуктивних стад залежить від ряду чинників, які прямо або опосередковано впливають на ефективність виробництва молока. Першочергову роль займає удосконалення племінних і продуктивних якостей худоби $[4,6]$ на основі одержання відтворення кращих генотипів, які при реалізації генетичної інформації поєднують у собі високу і стабільну продуктивність з відтворювальною здатністю $[2,5]$. Це зумовлює актуальність проведення подальших порівняльних досліджень впливу бугаїв, породи та відтворювальної здатності на галузь молочного скотарства.

Матеріали та методи досліджень. Дослідження проведені у стаді ДПДГ “Олександрівське" Вінницької області на тваринах українських червоно-рябої (УЧРМ, n = 474), чорно-рябої (УЧР, $\mathrm{n}=375)$ молочних та голштинської $(\Gamma, \mathrm{n}=395)$ порід. Враховували 7 показників відтворювальної здатності телиць і корів (вік першого осіменіння, вік першого отелення, тривалість тільності, сервіс-період, сухостійний період, міжотельний період і коефіцієнт відтворювальної здатності) за загальноприйнятими методами.

Коефіцієнт відтворювальної здатності (КВ3) корів вираховували за формулою:

де МОП - міжотельний період, днів.

$$
\text { КВ3 }=\frac{365}{\text { MOП }}
$$

Для аналізу використовували матеріали племінного обліку (Форма 2-мол) за 2011-2016 роки. Середні показники надоїв за вищу лактацію становили: голштинська - 6469 кг, українська чорно-ряба молочна - 6541 кг і українська червоно-ряба молочна - 6650 кг молока. Рівень годівлі складає 60-65 ц кормових одиниць на корову в рік. Обчислення здійснювали у форматі програмного пакету «STATISTICA-8,0» [1] на ПК за методикою Н. А. Плохинского [3].

Результати досліджень. Встановлено, що телички голштинської, українських червонорябої і чорно-рябої молочних порід були осіменені у віці 18,1, 19,1 і 18,9 місяців (табл. 1). Відповідно вік першого отелення у них становив 27,6, 28,7 і 28,4 місяців. Період від запуску дійних корів до отелення був у межах оптимального показника і становив від 58 до 68 днів. Тільність тварин тривала в середньому 279-281 день. Середні показники сервіс-періоду в цих 
порід становили від 135 до 164 днів, відповідно міжотельний період у них був 414-443 дні, що значно більше від оптимального показника на 44-74 і 50-78 днів. Коефіцієнти відтворювальної здатності були у більшості випадків низькими і становили 0,84-0,92.

1. Характеристика відтворювальної здатності корів

\begin{tabular}{|c|c|c|c|c|c|c|c|c|c|}
\hline \multirow{3}{*}{ Показник } & \multicolumn{9}{|c|}{ Порода } \\
\hline & \multicolumn{3}{|c|}{ голштинська } & \multicolumn{3}{|c|}{$\begin{array}{c}\text { українська червоно- } \\
\text { ряба молочна }\end{array}$} & \multicolumn{3}{|c|}{$\begin{array}{c}\text { українська чорно- } \\
\text { ряба молочна }\end{array}$} \\
\hline & $\mathbf{n}$ & $\mathbf{M} \pm \mathbf{m}$ & $\mathbf{C v}$ & $\mathbf{n}$ & $\mathbf{M} \pm \mathbf{m}$ & $\mathrm{Cv}$ & n & $\mathbf{M} \pm \mathbf{m}$ & $\mathbf{C v}$ \\
\hline Вік першого осіменіння, днів & 395 & $545 \pm 5,4^{\mathrm{c}}$ & 19,6 & 474 & $575 \pm 6,5$ & 24,5 & 375 & $567 \pm 6,9^{\mathrm{a}}$ & 23,3 \\
\hline Вік першого отелення, днів & 396 & $829 \pm 6,0^{c}$ & 14,1 & 474 & $860 \pm 6,8$ & 16,7 & 375 & $852 \pm 7,2^{\mathrm{B}}$ & 16,1 \\
\hline $\begin{array}{l}\text { Тривалість першої тільності, } \\
\text { днів }\end{array}$ & 389 & $279 \pm 0,3$ & 1,8 & 474 & $280 \pm 0,2$ & 1,8 & 376 & $279 \pm 0,3$ & 1,9 \\
\hline $\begin{array}{l}\text { Тривалість другої тільності, } \\
\text { днів }\end{array}$ & 193 & $280 \pm 0,4$ & 1,8 & 340 & $280 \pm 0,3$ & 1,8 & 248 & $280 \pm 0,3$ & 1,8 \\
\hline $\begin{array}{l}\text { Тривалість третьої тільності, } \\
\text { днів }\end{array}$ & 100 & $281 \pm 0,6$ & 2,0 & 225 & $281 \pm 0,4$ & 2,1 & 155 & $281 \pm 0,4$ & 1,6 \\
\hline Сервіс-період 1 лактації, днів & 194 & $154 \pm 7,0$ & 63,7 & 340 & $164 \pm 6,3$ & 69,9 & 255 & $163 \pm 6,9$ & 67,6 \\
\hline Сервіс-період 2 лактації, днів & 102 & $147 \pm 9,2$ & 63,7 & 255 & $155 \pm 7,4$ & 71,3 & 155 & $135 \pm 7,9$ & 72,2 \\
\hline Сервіс-період 3 лактації, днів & 48 & $134 \pm 8,9$ & 45,6 & 133 & $150 \pm 8,8$ & 67,8 & 88 & $140 \pm 10,1$ & 67,2 \\
\hline $\begin{array}{l}\text { Тривалість сухостійного пері- } \\
\text { оду } 2 \text { лактації, днів }\end{array}$ & 195 & $58 \pm 1,5$ & 36,0 & 340 & $61 \pm 1,2$ & 35,3 & 255 & $61 \pm 1,4$ & 38,1 \\
\hline $\begin{array}{l}\text { Тривалість сухостійного пері- } \\
\text { оду } 3 \text { лактації, днів }\end{array}$ & 102 & $63 \pm 2,8$ & 45,1 & 225 & $65 \pm 2,0$ & 46,9 & 155 & $64 \pm 2,2$ & 43,3 \\
\hline $\begin{array}{l}\text { Тривалість сухостійного пері- } \\
\text { оду } 4 \text { лактації, днів }\end{array}$ & 48 & $64 \pm 4,2$ & 45,3 & 133 & $68 \pm 3,1$ & 52,5 & 88 & $66 \pm 2,8$ & 40,4 \\
\hline $\begin{array}{l}\text { Міжотельний період 1-2 лакта- } \\
\text { ції, днів }\end{array}$ & 195 & $433 \pm 7,0$ & 22,6 & 340 & $443 \pm 6,3$ & 26,1 & 255 & $441 \pm 6,9$ & 25,1 \\
\hline $\begin{array}{l}\text { Міжотельний період 2-3 лакта- } \\
\text { ції, днів }\end{array}$ & 102 & $427 \pm 9,1$ & 21,6 & 225 & $435 \pm 7,3$ & 25,3 & 155 & $415 \pm 7,7$ & 23,0 \\
\hline $\begin{array}{l}\text { Міжотельний період 3-4 лакта- } \\
\text { ції, днів }\end{array}$ & 48 & $414 \pm 9,0$ & 15,0 & 133 & $428 \pm 8,8$ & 23,6 & 88 & $422 \pm 9,9$ & 22,1 \\
\hline $\begin{array}{l}\text { Коефіцієнт відтворної здатно- } \\
\text { сті 1-2 лактації }\end{array}$ & 195 & $0,88 \pm 0,01$ & 18,6 & 340 & $0,86 \pm 0,01$ & 19,8 & 255 & $0,87 \pm 0,01$ & 20,3 \\
\hline $\begin{array}{l}\text { Коефіцієнт відтворної здатно- } \\
\text { сті 2-3 лактації }\end{array}$ & 102 & $0,89 \pm 0,02$ & 17,8 & 225 & $0,88 \pm 0,01$ & 20,2 & 155 & $0,92 \pm 0,01$ & 18,2 \\
\hline $\begin{array}{l}\text { Коефіцієнт відтворної здатно- } \\
\text { сті 3-4 лактації }\end{array}$ & 48 & $0,90 \pm 0,02$ & 14,2 & 133 & $0,84 \pm 0,01$ & 19,2 & 88 & $0,90 \pm 0,02$ & 17,3 \\
\hline
\end{tabular}

Примітка: ${ }^{\mathrm{a}}-\mathrm{P}<0,05$; $^{\mathrm{B}}-\mathrm{P}<0,01$; $^{\mathrm{c}}-\mathrm{P}<0,001$. Вірогідність різниці вказана при порівнянні $з$ найвищим значенням показника.

Телички голштинської породи були осіменені в більш ранньому віці порівняно з телицями українських червоно-рябої молочної на 30 днів $(\mathrm{P}<0,001)$ і чорно-рябої молочної - на 22 дні $(\mathrm{P}<0,05)$. Відповідно у них вік першого отелення був меншим на 31 день $(\mathrm{P}<0,001) \mathrm{i}$ на 23 дні $(\mathrm{P}<0,01)$.

Щодо мінливості середніх величин відтворювальної здатності слід відмітити високий показник коефіцієнта варіабельності сервіс-періоду, який був від 45,6 до 72,2\% і тривалості сухостійного періоду від 35,3 до 52,5\%. Середні показники мінливості були у віці першого осіменіння $\mathrm{Cv}=19,6$ - 24,5\%, віку першого отелення $\mathrm{Cv}=14,1-16,7 \%$, міжотельного періоду $\mathrm{Cv}=15,0-26,1 \%$ та коефіцієнта відтворювальної здатності $\mathrm{Cv}=14,2-20,3 \%$. Достатньо високу консолідованість має тривалість тільності. У цієї ознаки коефіцієнт мінливості становив $\mathrm{Cv}=1,6-2,1 \%$.

Таким чином більшість показників відтворювальної здатності маточного поголів'я стада знаходяться в незадовільному стані і потребують поліпшення.

Між надоєм за 305 днів 1 лактації з показниками відтворювальної здатності одержано різновекторні коефіцієнти кореляції (табл. 2). Фенотипова кореляція у більшості випадків була 
низькою, як додатною, так і від’ємною ( $\mathrm{r}=-0,001--0,278 ; \mathrm{r}=+0,006-+0,350)$. У 14 випадках з вірогідністю $\mathrm{P}<0,05-\mathrm{P}<0,001$.

2. Фенотипова кореляція надою за 305 днів 1 лактації з показниками відтворювальної здатності корів

\begin{tabular}{|c|c|c|c|c|c|c|}
\hline \multirow{3}{*}{ Ознаки які корелюють } & \multicolumn{6}{|c|}{ Порода } \\
\hline & \multicolumn{2}{|c|}{ голштинська } & \multicolumn{2}{|r|}{ УЧРМ } & \multicolumn{2}{|r|}{ УЧР } \\
\hline & n & $\mathbf{r} \pm \mathbf{m}_{\mathbf{r}}$ & $\mathbf{n}$ & $\mathbf{r} \pm \mathbf{m}_{\mathbf{r}}$ & n & $\mathbf{r} \pm \mathbf{m}_{\mathbf{r}}$ \\
\hline надій $\times$ вік $1^{\text {го } о т е л е н н я ~}$ & 302 & $+0,011 \pm 0,001$ & 403 & $-0,117 \pm 0,014$ & 315 & $-0,083 \pm 0,007$ \\
\hline надій × МОП 1-2 & 195 & $+0,322 \pm 0,104^{\mathrm{c}}$ & 338 & $+0,217 \pm 0,047^{\mathrm{c}}$ & 255 & $+0,255 \pm 0,064^{\mathrm{c}}$ \\
\hline надій × МОП 2-3 & 102 & $+0,062 \pm 0,004$ & 224 & $+0,085 \pm 0,007$ & 155 & $+0,138 \pm 0,019$ \\
\hline надій × МОП 3-4 & 48 & $+0,004 \pm 0,002$ & 132 & $-0,008 \pm 0,001$ & 88 & $+0,266 \pm 0,070^{\mathrm{a}}$ \\
\hline надій × КВ3 1-2 & 195 & $-0,350 \pm 0,122^{c}$ & 338 & $-0,278 \pm 0,077^{c}$ & 255 & $-0,296 \pm 0,088^{\mathrm{c}}$ \\
\hline надій × КВ3 2-3 & 102 & $-0,053 \pm 0,003$ & 224 & $-0,101 \pm 0,010$ & 155 & $-0,135 \pm 0,018$ \\
\hline надій × КВ3 3-4 & 48 & $-0,034 \pm 0,001$ & 132 & $-0,001 \pm 0,001$ & 88 & $-0,279 \pm 0,078^{\mathrm{c}}$ \\
\hline надій $\times$ СП 1 & 194 & $+0,318 \pm 0,101^{\mathrm{c}}$ & 336 & $+0,210 \pm 0,044^{\mathrm{c}}$ & 255 & $+0,253 \pm 0,064^{\mathrm{c}}$ \\
\hline надій $\times$ СП 2 & 102 & $0,060 \pm 0,004$ & 224 & $+0,085 \pm 0,007$ & 155 & $0,149 \pm 0,0^{\text {a }} 22$ \\
\hline надій × СП 3 & 48 & $+0,006 \pm 0,001$ & 132 & $-0,025 \pm 0,001$ & 88 & $0,253 \pm 0,064^{*}$ \\
\hline надій $\times$ Сух 2 & 195 & $-0,208 \pm 0,043^{\text {в }}$ & 338 & $-0,183 \pm 0,033^{c}$ & 255 & $-0,111 \pm 0,012$ \\
\hline надій $\times$ Сух 3 & 102 & $-0,031 \pm 0,001$ & 224 & $-0,108 \pm 0,011$ & 155 & $-0,107 \pm 0,011$ \\
\hline надій $\times$ Сух 4 & 48 & $-0,083 \pm 0,007$ & 132 & $0,049 \pm 0,002$ & 88 & $+0,191 \pm 0,036$ \\
\hline
\end{tabular}

Примітка: СП 1,2,3 - тривалість сервіс-періоду після 1, 2 та 3 отелень; Сух 2, 3 та 4 - тривалість сухостійного періоду перед 2,3 та 4 отеленнями; ${ }^{\text {a }}-\mathrm{P}<0,05$; $^{\mathrm{B}}-\mathrm{P}<0,01$; $^{\mathrm{c}}-\mathrm{P}<0,01$.

Проведено дисперсійний аналіз впливу породи, лінії та батьків на відтворювальну здатність корів (табл. 3). Встановлено, що сила впливу $\left(\eta^{2} x\right)$ батьків була найвищою і становила 10,0-43,6\%, потім лінії - 2,3-25,5\% і відповідно породи - 0,1-1,0\%.

3. Сила впливу факторів на відтворювальну здатність корів різних порід

\begin{tabular}{|c|c|c|c|c|c|}
\hline \multirow[b]{2}{*}{ Фактор } & \multirow[b]{2}{*}{$\begin{array}{c}\text { Число гра- } \\
\text { дацій }\end{array}$} & \multirow[b]{2}{*}{$\begin{array}{l}\text { Об’см ком- } \\
\text { плексу }\end{array}$} & \multicolumn{3}{|c|}{ Сила впливу $\left(\eta^{2}\right.$ \% \%) на } \\
\hline & & & 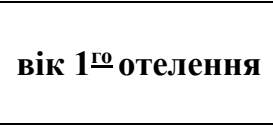 & $\begin{array}{c}\text { коефіціснт відтворюва- } \\
\text { льної здатності }\end{array}$ & $\begin{array}{c}\text { трива- } \\
\text { лість сер- } \\
\text { віс-період }\end{array}$ \\
\hline Порода & 3 & 1243 & 1,0 & 0,1 & 0,2 \\
\hline \multicolumn{6}{|c|}{ Голштинська } \\
\hline Лінія & 7 & 382 & 13,0 & 10,2 & 9,6 \\
\hline Батько & 18 & 358 & 37,9 & 19,7 & 18,9 \\
\hline \multicolumn{6}{|c|}{ Українська чорно-ряба молочна } \\
\hline Лінія & 11 & 353 & 25,5 & 6,2 & 5,3 \\
\hline Батько & 27 & 333 & 40,5 & 11,2 & 10,5 \\
\hline \multicolumn{6}{|c|}{ Українська червоно-ряба молочна } \\
\hline Лінія & 9 & 456 & 24,6 & 3,0 & 2,3 \\
\hline Батько & 16 & 425 & 43,6 & 10,0 & 10,0 \\
\hline
\end{tabular}

Висновки. Більшість показників відтворювальної здатності корів усіх порід знаходяться в незадовільному стані і потребують поліпшення. Так, середні показники сервіс-періоду у корів цих порід становили від 135 до 164 днів, відповідно міжотельний період у них був 414-443 дні, що значно більше від оптимальних показників на 45-74 та 49-78 днів.

Фенотипова кореляція між надоєм за 305 днів 1 лактації з показниками відтворювальної здатності у більшості випадків була низькою, як додатною, так і від’ємною ( $\mathrm{r}=-0,001$ - $0,278 ; \mathrm{r}=+0,006-+0,350)$.

Сила впливу $\left(\eta^{2} \mathrm{x}\right)$ батьків на відтворювальну здатність корів була найвищою і становила 10,0-43,6\%, потім лінії-2,3-25,5\% і відповідно породи - 0,1-1,0\%. 


\section{БІБЛІОГРАФІЯ}

1. Боровиков, B. STATISTICA: искусство анализа данных на компьютере. Для профессионалов / В. Боровиков. - СПб : Питер, 2003. - 688 с.

2. Гончар, О. Ф. Селекційні аспекти формування відтворної здатності у корів молочних порід / О. Ф. Гончар, Ю. М. Сотніченко // Розведення і генетика тварин : міжвід. темат. наук. зб. - К., 2015. - Вип. 50. - С. 200-207.

3. Плохинский, Н. А. Биометрия / Н. А. Плохинский. - Новосибирск, 1961. - 365 с.

4. Порівняльна характеристика молочної продуктивності корів українських червоно-рябої, чорно-рябої молочних та голштинської порід у ДПДГ «Олександрівське» / М.В. Гладій, Г. С. Коваленко, С. В. Прийма, Г. О. Гольоса, А. В. Тучик, Л. В. Марчук, В. П. Оцабрик, Б. Б. Льоля // Розведення і генетика тварин : міжвід. темат. наук. зб. - К., 2016. - Вип. 52. C. 6-12.

5. Рудик, І. А. Рівень відтворної здатності корів як фактор формування високопродуктивних стад молочної худоби / І. А. Рудик, В. П. Олешко // Науковий вісник НУБіП. - К., 2011. Вип. 160. - ч.1. - С. 34-41.

6. Федорович, С. І. Молочна продуктивність високопродуктивних корів та їх потомків Прикарпатського внутрішньопородного типу української червоно-рябої молочної породи / Є. І. Федорович, О. Ю. Ільницька, Н. П. Бабік // Розведення і генетика тварин : міжвід. темат. наук. зб. - К., 2016. - Вип. 52. - С. 119-128.

\section{REFERENCES}

1. Borovikov, V. 2003. STATISTICA: Isskustvo analiza dannykh na komp'yutere: dlya professionalov-STATISTICS: Art of computer data analysis: for professionals. S.-Peterburg, Piter, 688 (in Russian).

2. Honchar, O. F., and Yu. M. Sotnichenko. 2015. Selektsiyni aspekty formuvannya vidtvornoyi zdatnosti u koriv molochnykh pored - Selection aspects of reproductive ability formation in dairy cows. Rozvedennya i henetyka tvaryn : mizhvidomchyy naukovyy zbirny. Breeding and genetics of animals : interdepartmental thematic scientific collection. Kyiv, Ahrarna nauka, 50:200-207 (in Ukrainian).

3. Plohinskij, N. A. 1961. Biometriya - Biometrics. Novosibirsk, 365 (in Russian).

4. Hladiy, M. V., H. S. Kovalenko, S. V. Pryyma, H. O. Hol'osa, A. V. Tuchyk, L. V. Marchuk, and B. B. L'olya. 2016. Porivnyal'na kharakterystyka molochnoyi produktyvnosti koriv ukrayins'kykh chervono-ryaboyi, chorno-ryaboyi molochnykh ta holshtyns'koyi porid u DPDH «Oleksandrivs'ke» - Comparative description of cows Ukrainian red-and-white dairy cattle and Ukrainian black-and-white dairy cattle and Holstein breeds in SERF "Oleksandrivske". Rozvedennya $i$ henetyka tvaryn : mizhvidomchyy naukovyy zbirnyk - Breeding and genetics of animals : interdepartmental thematic scientific collection. Kyiv, Ahrarna nauka, 52:6-12 (in Ukrainian).

5. Rudyk, I. A., and V. P. Oleshko. 2011. Riven' vidtvornoyi zdatnosti koriv yak faktor formuvannya vysokoproduktyvnykh stad molochnoyi khudoby - The level of reproductive ability of cows as a factor in the formation of high-yielding herds of dairy cattle. Naukovyy visnyk NUBiP-Scientific. Bulletin of the NUBiP. 160:34-41 (in Ukrainian).

6. Fedorovych, Ye. I., O. Yu. Il'nyts'ka, and N. P. Babik. 2016. Molochna produktyvnist' vysokoproduktyvnykh koriv ta yikh potomkiv Prykarpat's'koho vnutrishn'o porodnoho typu ukrayins'koyi chervono-ryaboyi molochnoyi porody - High-milk productivity of high-producing cows and offsprings of interbreed precarpathian tipe of Ukrainian Red-and-White dairy breed. Rozvedennya $i$ henetyka tvaryn : mizhvidomchyy naukovyy zbirny - Breeding and genetics of animals : interdepartmental thematic scientific collection. Kyiv, Ahrarna nauka, 52:119-128 (in Ukrainian). 